\title{
TEACHING COMPUTER TECHNOLOGY AT A DISTANCE (A)
}

\begin{abstract}
Albert Ritzhaupt, Adjunct Instructor of Computer and Information Sciences at the University of North Florida (UNF) faced a dilemma in the fall semester of 2005. He was teaching a computer programming course online, CGS 3559 - Introduction to the Internet. For the first nine weeks of the course, his perception had been that things were running smoothly. That perception had just come to a screeching halt, as the course entered the web programming module. Suddenly, it had become very clear that students were having problems. The number of questions posted to the discussion board tripled. Emails with the subject line "I am confused" or "I am frustrated" began to fill his inbox. Of even greater concern, students had not even reached their first really challenging web programming assignment.
\end{abstract}

In designing and teaching the course, Ritzhaupt had faced three major challenges. First, he was working on his doctorate at the University of South Florida (USF) and living in Tampa, roughly 200 miles southeast of UNF and approximately a 4 hour drive. Second, because the course allowed any undergraduate with basic PC skills to enroll, he knew that the technical challenges related to the course objectives could easily overwhelm students lacking the necessary prerequisite technical skills. Finally, the course had not been offered in over four years at UNF. As a result, there had been little or no material to reference in designing the course. In addition, when previously offered, the course had only been given in a face-to-face format. The decision to deliver it in a distance learning format represented an experiment for the department. Like many other information technology-aligned programs across the country, the UNF Department of Computer and Information Sciences had experienced substantial enrollment drops as a result of a decline in interest in computing. Gaining additional Full-Time-Enrollment (FTE), by reaching out to the general university population, was a vital part of the department's strategy for maintaining its position within the university. Not only was this course supposed to increase the department's FTE, it was also intended to serve as a prototype for the use of online delivery to generate

\footnotetext{
This case was prepared for the purpose of class discussion, and not to illustrate the effective or ineffective handling of an administrative or classroom situation and is copyrighted by the Informing Science Institute. Permission to make digital or paper copy of part or all of these works for personal or classroom use is granted without fee provided that the copies are not made or distributed for profit or commercial advantage AND that copies 1) bear this notice in full and 2) give the full citation on the first page. It is permissible to abstract these works so long as credit is given. To copy in all other cases or to republish or to post on a server or to redistribute to lists requires specific permission and payment of a fee. Contact Publisher@InformingScience.org to request redistribution permission.
}

greater interest in computing.

Ritzhaupt recognized that if the online course was not a success, he would probably not be invited back to teach for UNF. That was a bridge that he did not intend to burn so early in his academic career. But what could he do to extricate himself from his current situation? 


\section{UNF Department of Computer and Information Sciences}

The University of North Florida (UNF) was a regional institution nestled among 1,300 scenic acres of wildlife in Jacksonville, Florida. UNF, opened in 1972, served approximately 15,000 students by offering 50 undergraduate degrees in 155 specializations, and 27 graduate degrees with 65 concentrations. UNF's primary focus was on instruction, with scholarship and community involvement playing vital roles.

Within UNF, the department of Computer and Information Sciences (CIS) was located in the College of Computing, Engineering, and Construction. CIS offered bachelors degrees in computer science, information systems, and information science. The department also offered master's degrees in computer science, information systems, and software engineering. The department had 21 full-time faculty and many additional adjunct instructors and teaching assistants. Historically, the department had experienced high enrollment. Recently, however, information technology-aligned degree programs nation-wide had suffered declines in enrollment as high as $75 \%$. These were generally attributed to a number of factors, including the bursting of the stock market "Internet Bubble" during 2000-2001, sluggish IT hiring following a rapid buildup of staff during the 1990s, and concerns relating to increased offshoring of IT jobs to locations such as Bangalore, India. The CIS department at UNF had not been immune from this phenomenon.

CIS students were exposed to an interdisciplinary curriculum in both business and computing. The computing course work students took for this program was reflective of current computing practices, whether legacy or state-of-art, as employed to implement solutions to business problems. This included coursework in applications programming, data and file structures, object-oriented design, system design, database design, systems implementation, systems maintenance, networks, and computer communications. Graduates were prepared to embark on careers ranging from software development specialists to information systems managers.

During the periods of high enrollment, the program flourished and had moved to escalate its status and academic rigors by adopting a Satisfactory Progress Policy. This policy had received university-wide attention while it was being integrated into the curriculum. Essentially, the policy had been established to counter problems with students registering and withdrawing from courses in multiple instances to avoid the "difficult" teachers. This weakest-link phenomenon created a problem for students trying to get into courses that would often fill within hours of opening registration. The Satisfactory Progress Policy stated that:

Students who do not successfully complete a CIS prerequisite or core requirement on the first attempt (i.e., earn a grade of D, F, W, WP or WF) will be granted one chance to repeat the course. Students who do not successfully complete a prerequisite or core requirement within two attempts will not be permitted to register for CIS courses in future semesters. This stipulation applies whether or not the student has declared a major in a CIS program.

Prior to Fall 2005, the CIS department regularly offered only one course online: CGS 1570

(Microcomputer Applications). CGS 1570 was a prerequisite to CGS 3559 and was one of the only courses offered by the CIS department that was required by other degree programs.

Although a number of earlier attempts had been made to offer CIS courses online, these had not generally met with great success. Faculty had found it complicated to teach rigorous software development and programming skills at a distance, and students found it extremely difficult to learn. As a result, the 
decision to offer an online programming course was a risky one. Computer programming courses were infamous for low retention rates. This fact, coupled with the Satisfactory Progress Policy and the need for increased FTE outside the department, made for a delicate situation.

CGS 3559 was not a required course in any degree program and would maximally serve as an upper-level free elective for any major. The CIS department was uncertain whether the course would meet its enrollment targets and would potentially cancel the section if it did not reach at minimum 25 students. Thus, Ritzhaupt had reached out to his colleagues in other colleges to advertise the offering as an upper level free elective that would be fun, challenging, and provide some essential skills in the information age. Three weeks after registration opened, the course reached its 30 student cap, with 10 additional students on the waiting list. The course would definitely be offered.

\section{CGS 3559 - Introduction to the Internet}

CGS 3559 covered a diverse set of Internet technologies and was intended to serve a diverse body of students. The course description was as follows:

Prerequisite: CGS 1570 or permission. Introduction to and use of browsers including helpers and plug-ins; html programming, including forms, image maps, and CGI scripts; production of graphics for the WEB; design of home pages.

Speaking to the department chair about the course, Ritzhaupt found that he would be given a great deal of flexibility in selecting the course topics as long as the course required individual work in three specific areas:

- Hyper-text Mark-Up Language (HTML): HTML is the language used to create and format web pages. Learning HTML requires students to practice writing HTML in a standard text editor, such as MS-Notepad. Since it is a mark-up language, students were expected to remember a number of "tags" to create functional and visually appealing websites.

- Basic client-side and server-side scripting: HTML by itself is static, meaning that once an HTML page is loaded into a web browser, is does not change or react to user activities. To learn how to create dynamic, interactive websites, students had to be exposed to both a server-side scripting language (PHP) and a client-side scripting language (Javascript). The primary difference between these two is that Javascript executes in the client's web browser, whereas PHP executes on the server housing the web pages.

- Basic computer network communications skills: Students were expected to have the skills necessary to set up a simple web server, meaning they should be able to configure a Linux account, setting various permissions, and use File Transfer Protocol (FTP) services to move files back and forth.

One of major goals of the course was to provide students with the skill sets necessary to create, manage, and maintain robust web-sites independently for their future or current employers. Ritzhaupt and his department chair felt that the course needed to serve as a vehicle for demonstrating a student's skill set upon completion. The outcome of the course needed to be a product that students could use to aid in the employment process-making their skills more marketable.

Student enrollment for the Fall of 2005 semester was approximately 57\% CIS students and 43\% students from other colleges. Even among the students coming from the department, exposure to programming could not be assumed. Since the only prerequisite course was the basic computer applications (Word 
Processors, Spreadsheets, etc.) course, some CIS students might not have taken a programming course prior to enrollment.

\section{Albert Ritzhaupt}

Albert Ritzhaupt had been teaching since the summer of 2003 at UNF, Florida Community College at Jacksonville (FCCJ), and, subsequently, at the University of South Florida. Upon completing his BS in Computer and Information Sciences (Honors in the Major, Magna Cum Laude) at UNF, he had enrolled in the MBA program, concurrently working as an adjunct instructor at FCCJ and as a teaching assistant at UNF. At the same time, Ritzhaupt worked part-time as a contract programmer for Blue Cross Blue Shield Florida (BCBSFL). While completing his MBA with 18 graduate hours in computer science, Ritzhaupt decided that teaching technology and pedagogical research were definitely going to be his longterm career goals.

In late 2004, Ritzhaupt decided to leave BCBSFL and work as a full-time instructor, teaching courses ranging from Object-Oriented programming to Microcomputer Applications. He kept abreast of the local IT industry by taking small consulting projects and by attending professional organization meetings. This facilitated finding his "best" students jobs in the local IT market. Upon completing his MBA, Ritzhaupt joined the University of South Florida (USF) as a doctoral student in their College of Education, pursuing his PhD in Instructional Technology and Educational Research and Measurement.

Ritzhaupt had an outcome-driven philosophy of teaching and learning. He believes that it was the responsibility of teacher to provide students an environment that closely resembled what they should expect in the real-world. He further believed that students should actively engage material, learning how to solve problems and think critically_not simply remember facts without a complete understanding of the material. He felt that instructional materials needed to be constructed with these objectives in mind.

\section{Designing the Course}

Prior to the fall of 2005, Ritzhaupt had taught only one course online (CGS-1570 at UNF), where he had experienced some degree of success. For that course, however, Ritzhaupt had used materials created by another teacher. Ritzhaupt knew the CGS-3559 course, needing to be constructed without a well defined roadmap, would represent a very different type of challenge.

As a first task, Ritzhaupt searched for an appropriate textbook to cover all the course objectives. Unsurprisingly, no such text existed. He texts he found were either too advanced or only covered some of the course topics. Consequently, he was forced to select a text that only covered three of the four major objectives. For the final objective (server-side scripting), he decided to write an e-book specifically for the course, a time-consuming choice that-he suspected-would either work very well or crash and burn. A portion of the e-book can be seen in Exhibit 1. He made this choice mainly because he felt that the other available options - forcing the students to purchase another textbook or patching together a collection of resources online-were decidedly inferior. He also had hoped that students would appreciate the time and money he was saving them.

His next task involved developing a syllabus, and a set of deliverables that would demonstrate student understanding of concepts. As part of the syllabus, Ritzhaupt required all students to send an enrollment email detailing previous computer experience and their score on an online self-assessment intended to help students decide whether a distance learning course suited their learning needs. The online assessment can be seen in Exhibit 2. 
Ritzhaupt chose to have his students develop an ePortfolio over the duration of the semester. The ePortfolio could be used to demonstrate skills to potential employers and would also meet the objectives of the course. An ePortfolio, as defined by the National Learning Infrastructure Initiative, is "a collection of authentic and diverse evidence drawn from a larger archive representing what a person or organization has learned over time on which the person or organization has reflected, and designed for presentation to one or more audiences for a particular rhetorical purpose.” An example of a student's ePortfolio can be seen in Exhibit 3.

In designing the course, two other major concerns needed to be addressed: (1) development of instructions and tutorials to aid students in configuring their websites on a Linux server and in using Secure Shell, a file transfer service, and (2) addressing how he would provide office hours to students living in Jacksonville when he was living in Tampa, over 200 miles away.

With respect to the first concern, it was critical that students understand how they should upload their assignments to a web server so they could be graded. Since Ritzhaupt had already invested a tremendous amount of time in developing the course, he chose not to use any innovative media technologies to demonstrate how to configure the student's Linux account or how to use Secure Shell. Instead, he offered students basic instructions with screen shots in Portable Document Formats (i.e., Adobe Acrobat ${ }^{\mathrm{TM}}$ PDF files). He thought that students would already be familiar with these technologies coming from CGS 1570. An example of the tutorial can be seen in Exhibit 4.

Providing students office hours was especially perplexing. Ritzhaupt wanted to help the students as much as he could but, at the same time, he did not want to receive cell phone calls throughout the day or fifty emails the night before an assignment was due. To handle communications from students, he decided he would post a discussion board thread for each week in the semester. He further required that all courserelated questions be posted to the discussion board—a requirement specifically stated in his syllabus. He considered this to be a risky approach. Nonetheless, he believed the risk was justified because the approach would enable students to answer each other's questions and prevent him from having to answer the same question multiple times. To provide the equivalent of office hours, he reserved four hours of his Friday morning to entertain questions via cell phone, email and instant messenger. Key portions of the course syllabus are provided in Exhibit 5.

The course was facilitated online using Blackboard, a well-known and widely used course management system. The course was organized with minimal menu options to reduce ambiguities. Each week's tasks were structured as reading assignments and activities and were outlined in a folder under assignments. External links to online resources were provided, and each assignment included very explicit instructions regarding the tasks to be completed and the related course materials. Sample screen shots of the course Blackboard site can be seen in Exhibit 6.

\section{First Eight Weeks}

The first week of class went by with the regular problems associated with an online course-nothing out of the ordinary. During the second week, students were required to complete their first assignment, which was contingent upon them correctly configuring their accounts in the previous week. All assignments were due Sunday night by 11:55pm. By Thursday of the second week, only five questions had been posted to the discussion board. This concerned Ritzhaupt because he thought students would have more problems setting up their accounts as part of the previous week's activities. By Saturday afternoon, the 
discussion board had over 60 postings, most of which involved students having technical problems correctly configuring their accounts or uploading their files to the server.

Spending the next 8-hours answering questions on the discussion board (and violating the course communication policy by taking phone calls and emails related to student problems), Ritzhaupt finally had assisted all his students over the first assignment hurdle. Ritzhaupt had been right in his estimation that students would not have too many problems doing the assignment. Unfortunately, he had grossly underestimated how many problems students would have configuring their accounts and uploading files using Secure Shell. For any subsequent semester, Ritzhaupt knew that he would have to find a better way to teach students how to upload files and configure their accounts-a very important lesson learned.

By the fourth week and second assignment, most of the students only had problems with the course subject matter being covered, HTML, and no longer reported issues relating to the PDF tutorials. Also, the communication policy was proving to be quite effective. Students began to answer each others questions in a professional and cordial manner, and Ritzhaupt did not receive too many emails that begged for help the day before the deadline of an assignment. It looked like the remainder of the course would proceed smoothly.

One minor technical problem did surface during this period. Out of the seven quizzes required to be completed online, four did not permit for multiple attempts. These quizzes were timed (20 minutes) so as to make it difficult for student to search for answers in the textbook as they proceeded through the quiz. Ritzhaupt had done this to ensure the students kept up with the reading. Students were warned on the syllabus to use a reliable Internet connection, and if they were concerned, to complete the quizzes in the computer lab where a lab assistant could document the incident and send Ritzhaupt an email. This policy did not work. Students would be locked out of the quizzes while working on their machines, and would need the instructor to unlock the quiz so they could be completed.

Ritzhaupt recognized that the Blackboard testing utility was not a perfect technology and neither was the World Wide Web-it was a "best effort" service. To provide a solution for the quiz problem, he chose to allow students to retake the quiz if they were locked out. However, he uploaded over 50 questions in each quiz pool, to be chosen randomly for each test. He felt that this would help reduce the likelihood that students would go through the quiz a first time in order to copy the questions for their next attempt. This solution appeared to work fairly well, although Ritzhaupt could not be completely sure that students weren't defeating the system in other ways — such as collaborating on the tests with another student or an IS professional.

\section{The Ninth Week}

At the beginning of the ninth week, the course appeared to be running smoothly. Few problems were being reported, assignments were being submitted on time, and most technical issues were easily resolved through the discussion board entries. As the week progressed, students were to begin the next step in their CGS 3559 journey: client-side scripting using Javascript. This activity was different from previous course activities in a number of ways. These included: using logic to solve problems, the use of variables in primary memory, and the implementation of a scripting language as oppose to a mark-up language.

By midweek, it was evident that many of the students were having problems completing the first Javascript assignment, by far the easier of the two assigned. Through emails and discussion board posts, Ritzhaupt determined that students were encountering a number of syntax errors related to their programs, and more importantly, they lacked an understanding of the basic concepts necessary to complete the 
assignments successfully. Client-side scripting was thoroughly addressed in the textbook that the students had purchased for the course, and students hadn't even started server-side scripting component (covered in the e-book written by Ritzhaupt). If students were having serious problems already, how would they react to subsequent assignments that demanded a higher degree of programming skills? An example of one of the client-side scripting assignments can be seen in Exhibit 7.

In light of the recent problems and questions, and drawing upon his prior experience in teaching face-toface computer programming courses, Ritzhaupt was reasonably sure that if he did not modify the upcoming assignments or offer an alternative path for course completion, many students would not be able to complete the assignments. He had overestimated the technical skills of the students entering the course. What bothered Ritzhaupt more was that the students would soon begin using the e-book he had written. He thought to himself: "What if I did not do a good job writing the text?" At this point in the semester, it was going to be very difficult to redesign the course. Furthermore, the goal of the course was to cover both client- and server-side scripting. If he removed the server-side scripting component, he was concerned that he would not be meeting the departmentally-specified objectives.

Time was of the essence. Ritzhaupt knew he had to find a quick and feasible alternative plan. If he chose to modify the upcoming assignments, it was still likely that students would encounter many challenging technical problems that would be extremely difficult to support in a true distance learning environment. He was also concerned that student dissatisfaction with their client-side activity might color their perception of his e-book, or that the book itself might not meet the instructional needs of his students. In a sense, he had painted a target on himself. All these concerns were compounded by the Satisfactory Progress Policy, which made problems in a CIS course much more serious-from the student's perspective - than they might be in other courses. What type of administrative complaints might arise from this situation?

If Ritzhaupt chose to ignore the problem, he knew that doing so would likely place the less technically astute students in the course at a severe disadvantage, leading to endless phone and email complaints and a non-normal course grade distribution that might be viewed as unfair. Furthermore, doing so could undermine the department's initiative to reach out to other students at the university before it even got started. On the other hand, if Ritzhaupt chose to reduce the difficulty of the upcoming assignments, it could potentially upset the department chair or more technically inclined students because it would diminish the rigor of this junior-level course.

Finally, it was late in the semester and a complete course redesign was impractical. Not only would it be difficult to communicate at a distance, but it could potentially alienate his department chair. Ritzhaupt did not want lose his opportunity to teach the course in forthcoming semesters-especially after placing so much time into the design of the course. What Ritzhaupt needed was a plan of action... 


\section{Exhibit 1: Screen Shot from PHP for the Novice Programmer}

Below is a screen shot from the e-book created for CGS 3559. The full text is available at: http://www.unf.edu/ rita0001/eresources/php_tutorials.

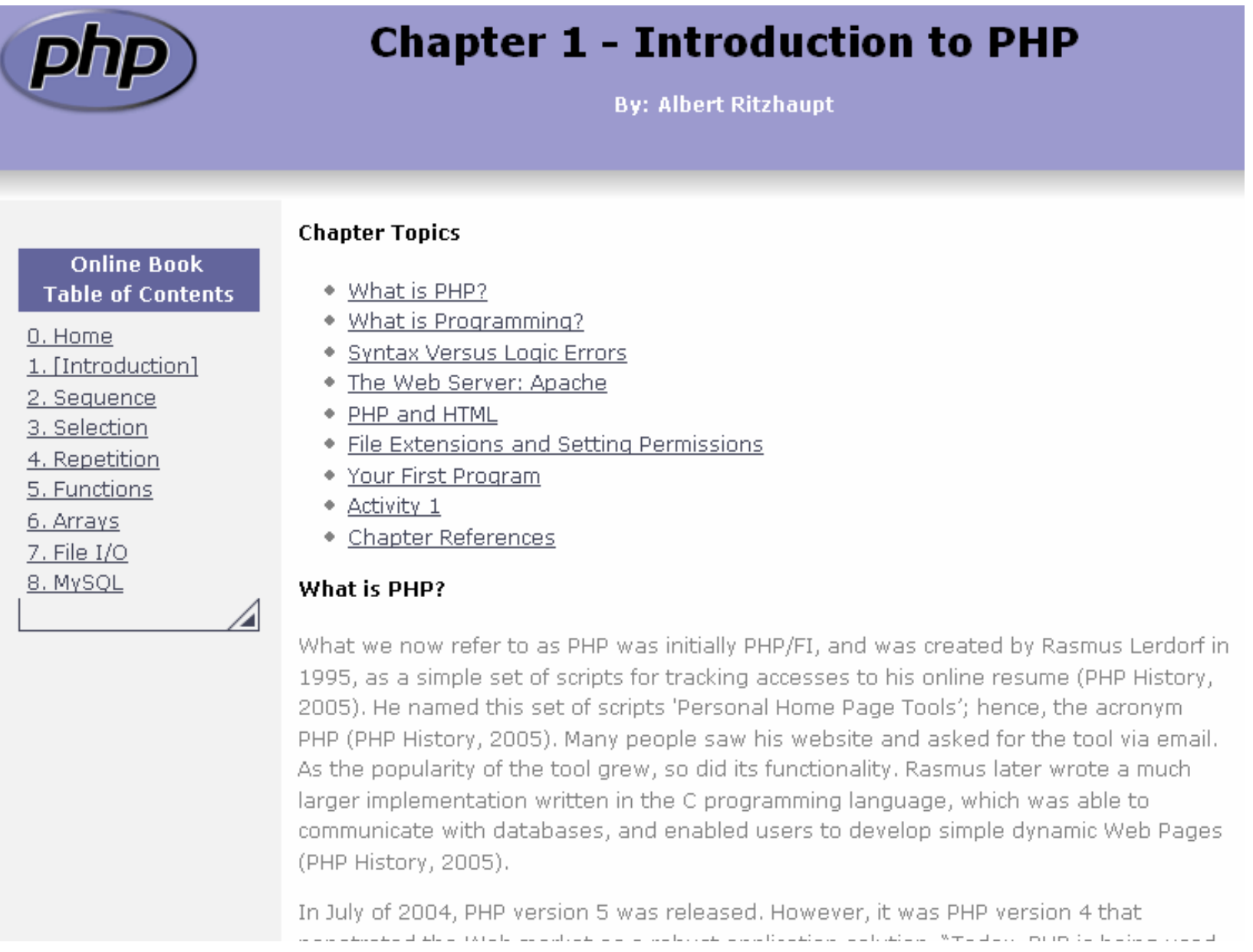




\section{Exhibit 2: Online Distance Learning Student Assessment}

This online self-assessment was used to help students make the right decision about whether or not to enroll in the course. In the event that a student received a low score, they were provided a warning by the instructor that distance learning courses require a great deal of self-motivation and time-management skills. The assessment is available at:

http://www.ccis.edu/online/admissions/selfassessment.asp

\section{Self Assessment Quiz}

\section{How well would Web-based courses fit your needs and lifestyle?}

Pick one answer for each question and click the "Score Survey" button. You may change your answers and re-score the survey as many times as you like.

1. My need to take this course now is

C high - I need it immediately for degree, job, or other important reason.

C moderate - I could take it on campus later or substitute another course.

C low - It's a personal interest that could be postponed.

2. Feeling that $I$ am part of a class is

Q not particularly necessary to me.

C somewhat important to me.

$\mathbf{C}$ very important to me.

3. I would classify myself as someone who

$\mathbf{C}$ often gets things done ahead of time.

C needs reminding to get things done on time.

$\mathbf{C}$ put things off until the last minute.

4. Classroom discussion is

C rarely helpful to me.

C sometimes helpful to me.

C almost always helpful to me.

5. When an instructor hands out directions for an assignment, I prefer

$\mathbf{C}$ figuring out the instructions myself. 
C trying to follow the directions on my own, then asking for help as needed.

$\mathbf{C}$ having the instructions explained to me.

6. I need faculty comments on my assignments

C within a few weeks, so I can review what I did.

$\mathrm{C}$ within a few days, or I forget what I did.

C right away, or I get very frustrated.

7. Considering my professional and personal schedule, the amount of time $I$ have to work on Web-based courses is

C more than enough for a campus class or Web-based course.

$\mathrm{C}$ the same as for a class on campus.

C less than for a class on campus.

8. When I am asked to use VCRs, computers, voice mail, or other technologies new to me

C I look forward to learning new skills.

C I feel apprehensive, but try it anyway.

I I put it off and try to avoid it.

9. As a reader, I would classify myself as

C good - I usually understand the text without help.

$\mathrm{C}$ average - I sometimes need help to understand the text.

C slower than average.

\section{If I have to go to the campus to take exams or complete work}

C I can go to campus anytime.

C I may miss some lab assignments or exam deadlines if campus labs are not open evenings and weekends.

C I will have difficulty going to the campus, even in the evenings and on weekends. 


\section{Exhibit 3: Student Course ePortfolio Example}

This is an example of a student's ePortfolio. Each assignment required students to provide a brief description in their words, a list of learning objectives, and a link to and from the assignment and ePortfolio.

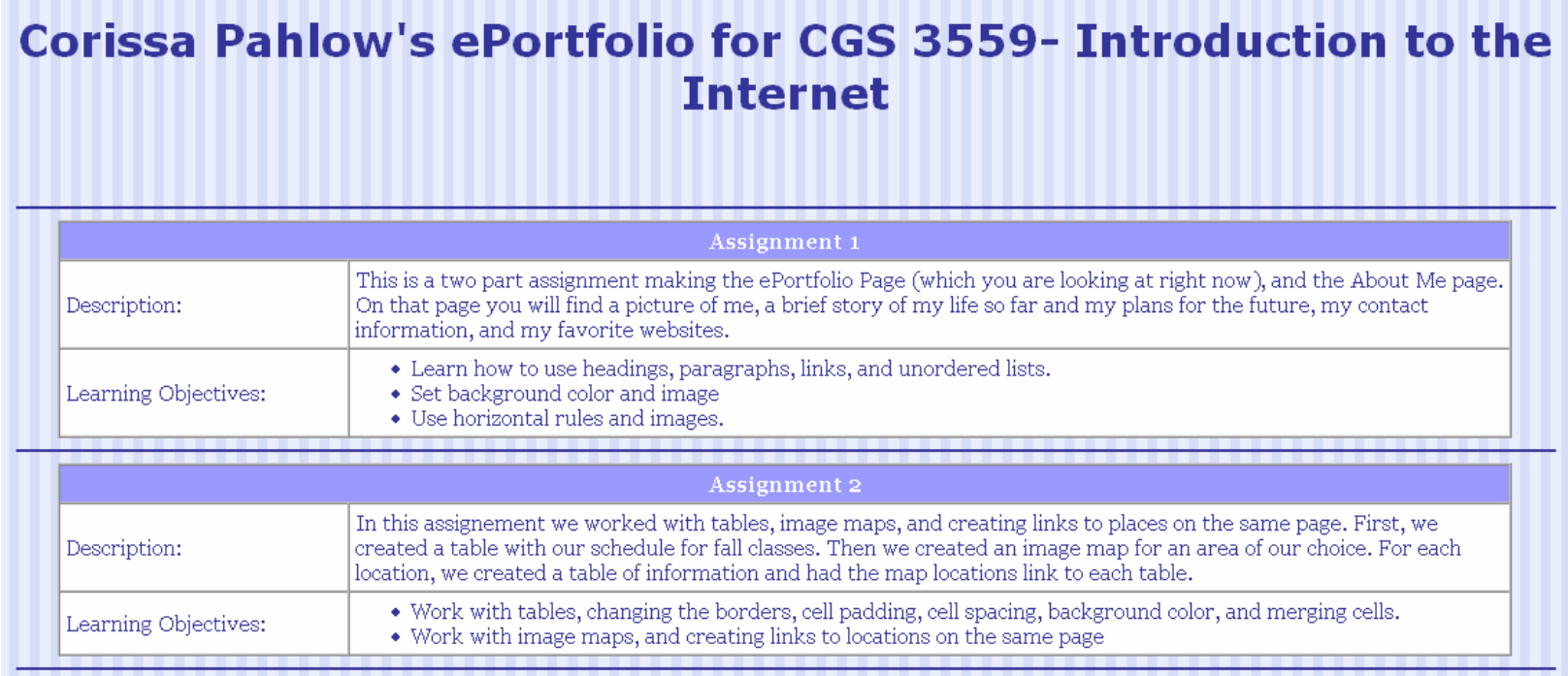




\section{Exhibit 4: Portion of PDF Tutorial}

This is a portion of one of the tutorials used to aide students in configuring their Linux accounts. Each task provided a screen shot and simple instructions.
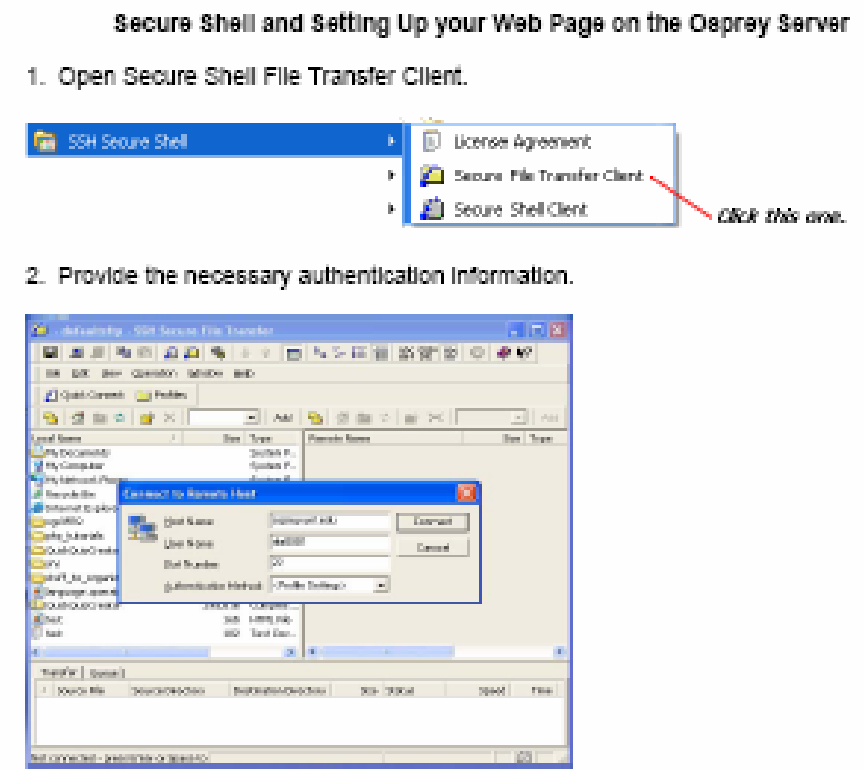

3. Press Connect, provide your password, and press okay.

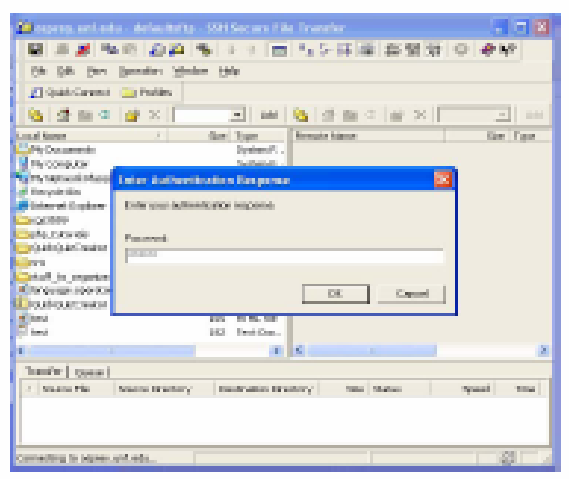




\section{Exhibit 5: Important Portions of the Syllabus}

This exhibit includes the elements of the syllabus that are germane to the development of the case. Some superfluous elements have been omitted.

\section{COURSE SYLLABUS \\ CGS 3559 - Introduction to the Internet \\ Distance Learning Course}

\section{COURSE DESCRIPTION}

Introduction to and use of browsers including helpers and plug-ins; html programming, including forms, image maps, and CGI scripts; production of graphics for the WEB; design of home pages.

\section{INSTRUCTOR INFORMATION}

Name: Albert Ritzhaupt, MBA, CCP

Email: rita0001@unf.edu

Website: http://www.unf.edu/ rita0001

\section{VIRTUAL OFFICE HOURS}

I will have virtual office hours on Friday, from 10:00am to 2:00pm. You may contact me via phone, instant messenger (aritzhaupt80, aol), or email (rita0001@unf.edu) during the specified time. All other questions should be directed to Black Board.

\section{ENROLLMENT PROCEDURES}

After registering, email the instructor (rita0001@unf.edu) before the start of class for a detailed syllabus and instructions regarding logging into Black Board, the application that will be used to deliver the course.

In your email, include the following:

- your full name

- your intended or declared major

- statement of previous computer experience

- statement that you have read and understand the all the information contained within this document

- your score on the online learning self-assessment quiz

\section{SCHEDULE}

All assignments, quizzes, and discussion questions are due on Sunday night at 11:55pm - no exceptions. There will be no late submissions accepted in this course unless medical documentation is provided. My advice is to consider Friday of each week to be the deadline for all submission and save your weekends for pleasure or studying for other classes.

This course is largely deadline-oriented and requires a great deal of self-motivation and selfconfidence. Each week is divided into two parts: weekly reading assignment and weekly activities. The weekly reading assignment means that you should read and complete the project material in each chapter of the HTML: Comprehensive Concepts and Techniques and PHP for 
the Novice Programmer book. You are to complete the reading before you begin the activities. At any given point in time after the project chapter is completed, the instructor reserves the right to request to see your homework assignment (project in chapter). If you cannot produce this with in 48 hours of the request, points will be deducted from your final grade in the course.

\section{TENTATIVE SCHEDULE}

\begin{tabular}{|c|c|}
\hline Week 1 & $\begin{array}{l}\text { Weekly Reading Assignment: } \\
\text { - Project 1: Introduction to HTML } \\
\text { - Project 2: Creating and Editing Web Pages } \\
\text { - Secure Shell Instructions } \\
\text { Weekly Activities: } \\
\text { - Project } 1 \text { and Project } 2 \text { Quiz (quiz 1, multiple attempts) } \\
\text { - Download and Install Secure Shell }\end{array}$ \\
\hline Week 2 & $\begin{array}{l}\text { Weekly Reading Assignment: } \\
\text { - Project 3: Creating Web Pages with Links, Images, and Formatted } \\
\text { Text } \\
\text { - Linux account creation, creating directories, and setting } \\
\text { permissions using Secure Shell Tutorial } \\
\text { Weekly Activities: } \\
\text { - Configure Osprey Account } \\
\text { - Assignment } 1\end{array}$ \\
\hline Week 3 & $\begin{array}{l}\text { Weekly Reading Assignment: } \\
\text { - Project 4: Creating Tables in a Web Site } \\
\text { Weekly Activities: } \\
\text { - Project } 3 \text { and } 4 \text { Quiz (quiz 2, one attempt only) }\end{array}$ \\
\hline Week 4 & $\begin{array}{l}\text { Weekly Reading Assignment: } \\
\text { - Project 5: Creating an Image Map } \\
\text { Weekly Activities: } \\
\text { - Assignment } 2\end{array}$ \\
\hline Week 5 & $\begin{array}{l}\text { Weekly Reading Assignment: } \\
\text { - Project 6: Using Frames in a Web Site } \\
\text { Weekly Activities: } \\
\text { - Project } 5 \text { and } 6 \text { Quiz (quiz 3, multiple attempts) }\end{array}$ \\
\hline Week 6 & $\begin{array}{l}\text { Weekly Reading Assignment: } \\
\text { - Project 7: Creating a Form on a Web Page } \\
\text { Weekly Activities: } \\
\text { - Assignment } 3\end{array}$ \\
\hline Week 7 & $\begin{array}{l}\text { Weekly Reading Assignment: } \\
\text { - Project 8: Creating Style Sheets } \\
\text { Weekly Activities: } \\
\text { - Project } 7 \text { and } 8 \text { Quiz (quiz 4, one attempt only) }\end{array}$ \\
\hline Week 8 & $\begin{array}{l}\text { Weekly Reading Assignment: } \\
\text { - Project 9: Integrating Java Script and HTML } \\
\text { Weekly Activities: } \\
\text { - Assignment } 4\end{array}$ \\
\hline
\end{tabular}




\begin{tabular}{|c|c|}
\hline Week 9 & $\begin{array}{l}\text { Weekly Reading Assignment: } \\
\text { - Project 10: Creating Pop-up Windows, Adding Scrolling } \\
\text { Messages, and Validating Forms } \\
\text { Weekly Activities: } \\
\text { - Project } 9 \text { and } 10 \text { Quiz (quiz 5, one attempt only) }\end{array}$ \\
\hline Week 10 & $\begin{array}{l}\text { Weekly Reading Assignment: } \\
\text { - Project 11: Using DHTML to Enhance Web Pages } \\
\text { Weekly Activities: } \\
\text { - Assignment } 5\end{array}$ \\
\hline Week 11 & $\begin{array}{l}\text { Weekly Reading Assignment: } \\
\text { - PHP Chapter } 1 \\
\text { - PHP Chapter } 2 \\
\text { Weekly Activities: } \\
\text { - PHP Tutorial Quiz } 1 \text { and } 2 \text { (quiz 6, multiple attempts) }\end{array}$ \\
\hline Week 12 & $\begin{array}{l}\text { Weekly Reading Assignment: } \\
\text { - } \text { PHP Chapter } 3 \\
\text { - } \text { PHP Chapter } 4 \\
\text { Weekly Activities: } \\
\text { - Assignment } 6 \\
\text { - } \text { Final Project Assigned }\end{array}$ \\
\hline Week 13 & $\begin{array}{l}\text { Weekly Reading Assignment: } \\
\text { - PHP Chapter } 5 \\
\text { - PHP Chapter } 6 \\
\text { Weekly Activities: } \\
\text { - PHP Tutorial Quiz } 5 \text { and } 6 \text { (quiz 7, one attempt only) }\end{array}$ \\
\hline Week 14 & $\begin{array}{l}\text { Weekly Reading Assignment: } \\
\text { - PHP Chapter } 7 \\
\text { - PHP Chapter } 8 \\
\text { Weekly Activities: } \\
\text { - Assignment } 7\end{array}$ \\
\hline Week 15 & $\begin{array}{l}\text { Weekly Reading Assignment: } \\
\text { - None } \\
\text { Weekly Activities: } \\
\text { - Final Project Due }\end{array}$ \\
\hline Week 16 & $\begin{array}{l}\text { Weekly Reading Assignment: } \\
\text { - None } \\
\text { Weekly Activities: } \\
\text { - Final Project Evaluation Due } \\
\text { - ISQ Online }\end{array}$ \\
\hline
\end{tabular}

\section{COURSE DELIVERABLES}

\section{Assignments}

All the assignments will be due Sunday by $11: 55 \mathrm{pm}$. The assignments are designed to provide practice using the software tools. The assignments prove both expertise and knowledge of the tools you will be learning. The assignments will generally be based off of projects found within 
the textbook. All assignments will be delivered to the digital drop box in Blackboard providing a link to the designated location. The assignments will lead to the final projects, which is one of the core themes of this course. Special Note: There are seven assignments provided. Only six of the seven assignments are required in this course. If you complete all seven, you will receive extra credit points. If you are not a computer information science student or do not have prior programming experience, I advise you to complete the first six assignments.

\section{Quizzes}

All the quizzes will be due Sunday by 11:55pm. The quizzes are designed to ensure you are reading and understand the material. The quizzes will be online and available under Assignments in Black Board. Once you have taken the quiz, immediate feedback will be provided. Three of the seven quizzes will permit multiple attempts, which will allow you to take the quiz multiple times until you reach the desired score. My advice is to ensure you score a $100 \%$ on all the quizzes that allow multiple attempts. The other four quizzes will only allow one attempt. Complete the online quizzes on a reliable Internet connection. If you are concerned about taking the quiz on a reliable Internet connection, you should go to the third floor computer lab in building 15, and take the quiz there. If you are locked out for some strange reason, either a tutor or lab assistant in the lab must call me or send me an email in order for me to unlock quiz. If you exceed the time limit, you will not be allowed to take the quiz over. One point will be deducted for each minute over the time limit.

\section{Final Project}

The final project is the primary deliverable in this course. Requirements will be provided. The final projects will include skills and knowledge gained throughout the semester. All the final projects will be peer-reviewed by two anonymous reviewers. Their evaluation will be considered as part of your final score.

\section{INSTRUCTOR STUDENT CONTACT}

This course will use Black Board as a means of communication. All questions related to the course material should be submitted to Black Board. Emails will only be answered regarding personal matters unless otherwise specified. When emailing the instructor, you must include your full name, the course you are enrolled in (including the section number), and a clear description of the matter.

\section{ATTENDANCE POLICY}

Students must log in to the class in Black Board during the first two days of the term in order to fulfill the department's attendance policy of attending the first class meeting. Students not logging in to the course during that period may be dropped from the class in order to permit access to those on the waiting list.

\section{GRADING SCALE}

- $\quad+$ Assignments (7) - (30\%)

- Quizzes (7) - (35\%)

- Final Project (1) - (30\%)

- *Quality of Work - (5\%)

\begin{tabular}{|l|l|}
\hline Grade & Scale \\
\hline A & $90-100$ \\
\hline B & $80-89$ \\
\hline C & $70-79$ \\
\hline D & $60-69$ \\
\hline F & $0-59$ \\
\hline
\end{tabular}


+There are seven assignments provided. Only six of the seven assignments are required in this course. If you complete all seven, you will receive extra credit points. If you are not a computer information science student or do not have prior programming experience, I advise you to complete the first six assignments.

*The plus and minus grades can and will be assigned at the discretion of the instructor. This assignment will be based on the quality of the work submitted throughout the semester. Students in this course are expected to meet ALL deadlines and submit college-level work.

\section{TEXTBOOK INFORMATION}

Purchase the book before the class commences. All the texts listed here are required. Please do not wait until later in the term to try to purchase the texts, as they will be sold out, and this will not be accepted as an excuse for late work.

- Shelly, Cashman, Woods, Dorin, “HTML: Comprehensive Concepts and Techniques”, Third Edition, ISBN: 0-619-25503-X, 2005.

- Ritzhaupt, Ritzhaupt “PHP for the Novice Programmer," $1^{\text {st }}$ edition, Available at: http://www.unf.edu/ rita0001/eresources/php_tutorials/. This text was written by the instructor to be a resource to students in this course and to save students money. Your suggestions for improvement are welcome, but keep in mind, the book did not endure a rigorous editing process. 


\section{Exhibit 6: Screen Shots from Blackboard}

This screenshot is what a student would typically see upon logging into the Blackboard system and entering the course.

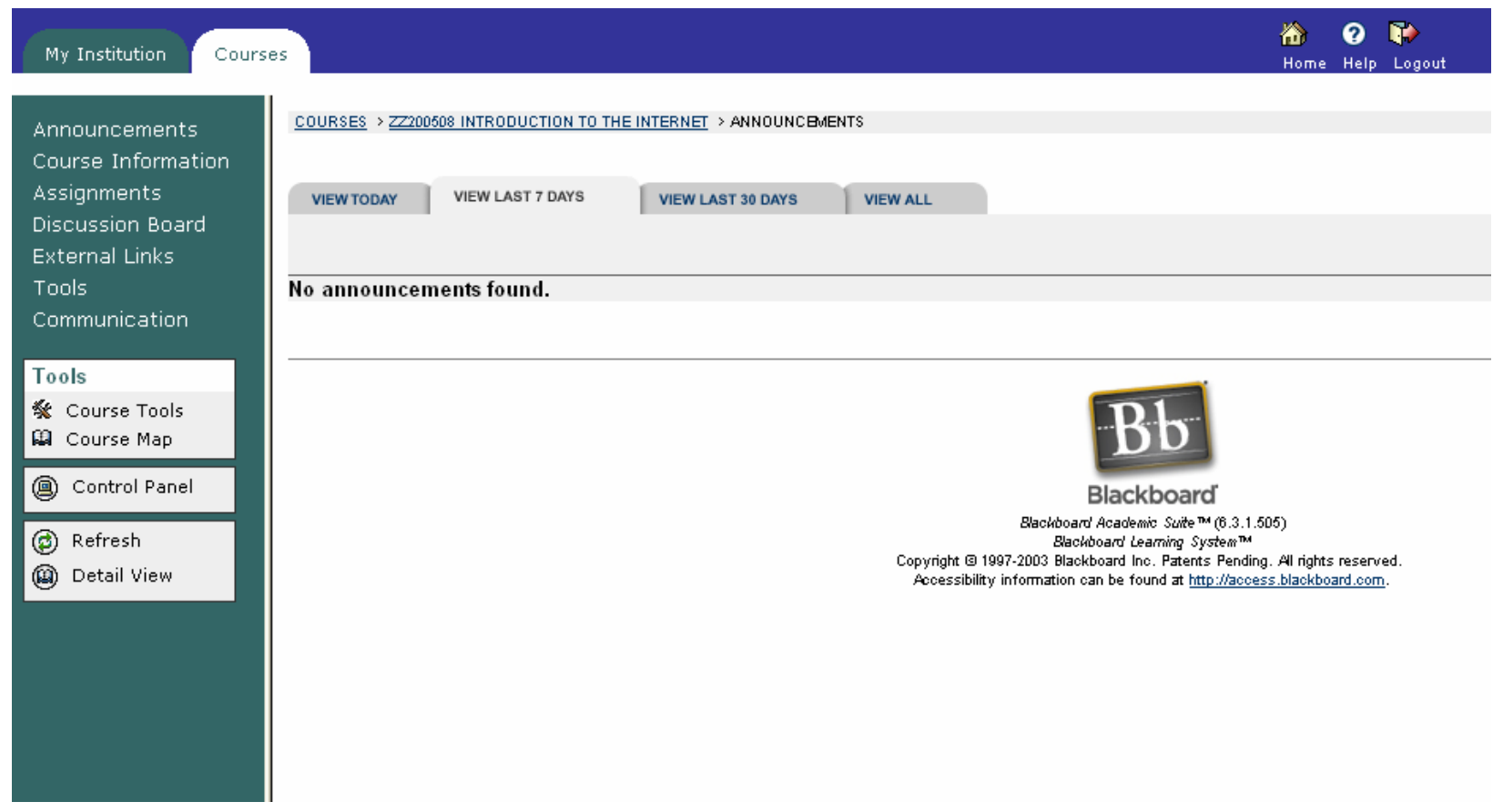

This screen shot visualizes how the course material is organized.

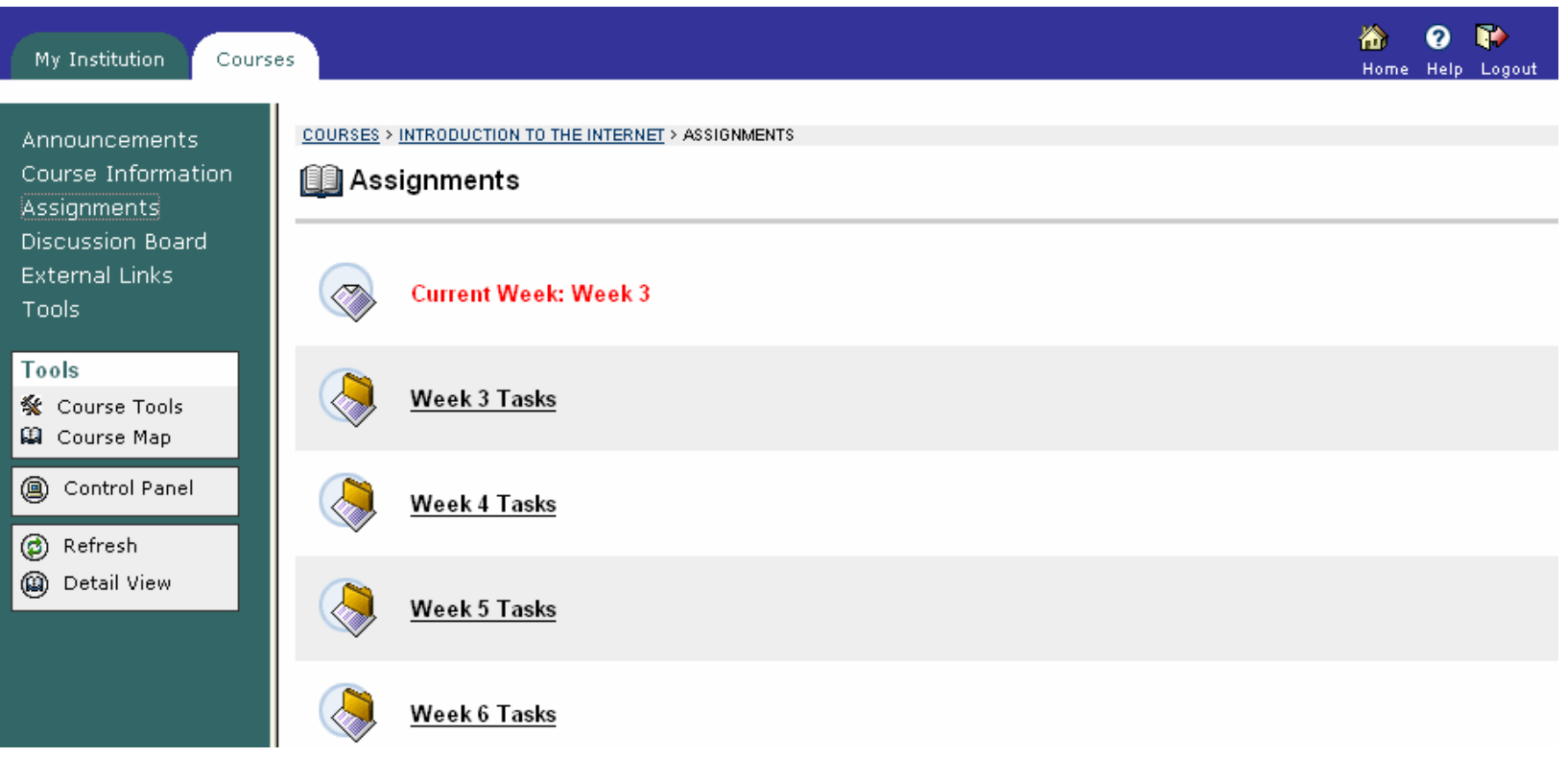


This screen shot displays the typical weekly task a student would expect to complete.

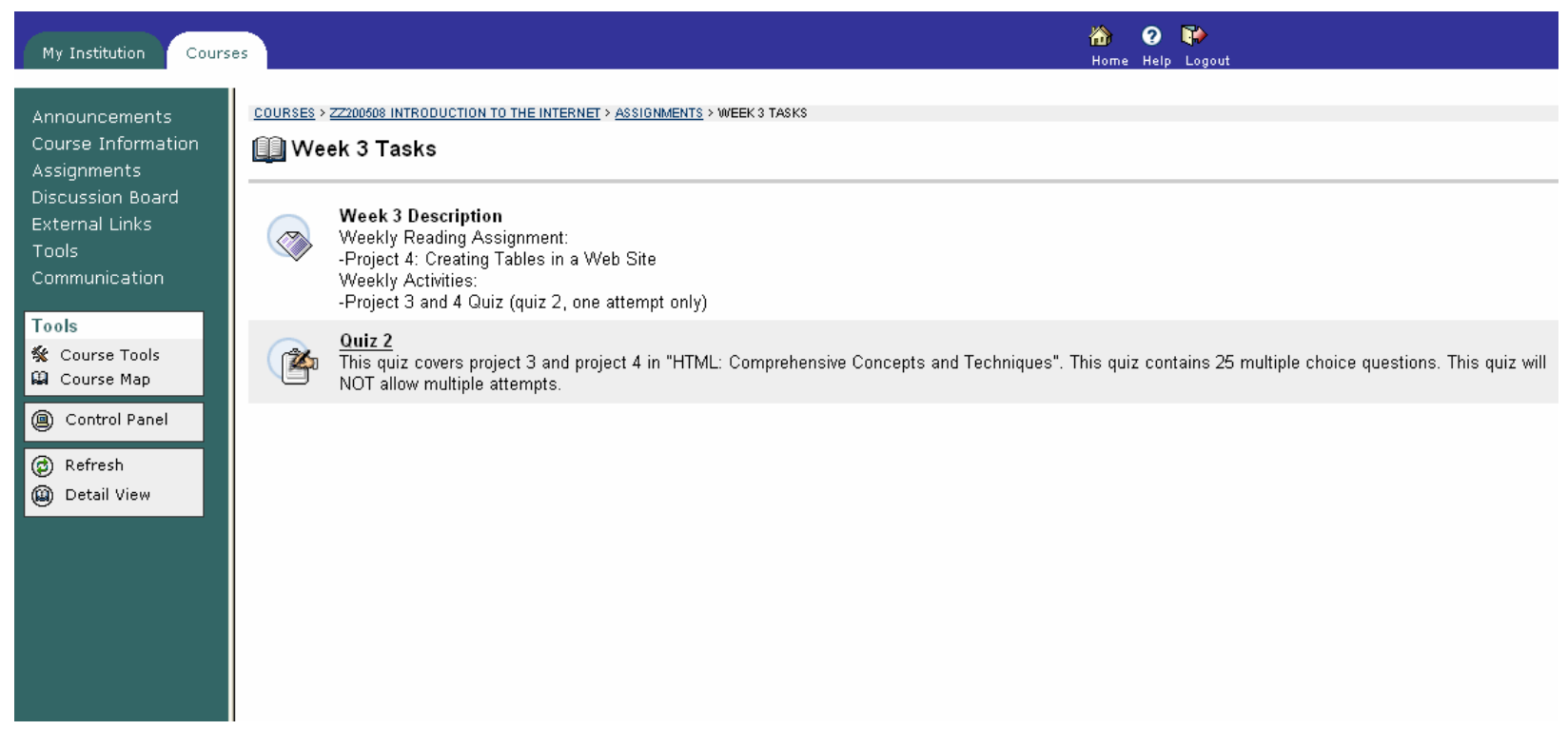




\title{
Exhibit 7: Sample Assignment
}

\author{
Assignment 5 - Form Validation and DHTML \\ October 30, 2005 \\ Fall of 2005
}

\section{Delivery Instructions}

After completing the assignment, you are to submit a text file containing an active link to the assignment to the digital drop box in Blackboard. Additionally, the text file should contain links to any resources (backgrounds, images, graphics, etc) that you found on the Internet that were used in this assignment. The assignment is due October 30, 2005 at 11:55pm - no exceptions.

\section{Directory Structure}

1. http://www.unf.edu/ username/cgs3559//index.html - Update the ePortfolio with description of assignment in your own.

2. http://www.unf.edu/ username/cgs3559/assign5/index.html - Interactive Price Analysis form built using Java Script with DHTML effects.

\section{Assignment Description}

This is your fifth web page assignment. In this assignment, you will be exercising your skills in Java Script to validate forms and to perform simple calculations. Additionally, you will implement basic DHTML effects in your web page.

\section{Part 1}

In the first part of the assignment, you are to create a Price Analysis calculator. This calculator should be built using an HTML form and Java Script, similar to the Loan Payment Calculator found in Project 10. The form should include the following fields:

- Projected Units - The anticipated number of units to be sold.

- Total Fixed Cost - A cost that does not vary with the number of units.

- Variable Unit Cost - A cost varies in direct proportion to the number of units.

- Target Profit - The residual after all costs are deducted from revenue.

- Unit Price - The target price derived from the following equation:

Unit Price $=($ Total Fixed Cost + Variable Cost $*$ Projected Units + Target Profit $) /$ Projected Units

The form should request the variables from the user as shown above. The form should validate that all the fields are numeric and are greater than zero. If the criteria are not met, the user should receive an error message instructing what must be fixed. The user should only receive ONE error message that describes ALL the errors to be fixed.

Assuming the Java Script program is correct; the program should calculate the unit price and show the Unit Price in a textbox. The Unit Price should be currency formatted. Use a table to format the form layout. 


\section{Part 2}

In the second portion of the assignment, you are to create ScreenTips for each of the textboxes. When the user hovers over the textbox, a description of the field should appear as shown in Project 11. The ScreenTip should provide the definition of the field using the definitions provided above or a similar accounting definition. The ScreenTip can contain any combination of colors that is conducive to the look-and-feel of the form.

In addition to the ScreenTips, the form should also have a rotating banner of an image that is of a business or financial nature, such as dollar signs. Place the rotating banner in a location that does not distract the user. Use a Graphics program, such as Paint, to create the set of images.

Finally, you should create an HTML file that provides instructions on How to Use the Price Analysis Calculator. You are welcome to use a combination of images and text to express your ideas. This page should have a Close Instructions link that closes the browser window when clicked. Add a link to your Interactive Price Analysis Calculator form links to this HTML file. It should open the window using a Java Script pop-up window that does not contain any file menu or toolbar options. Make sure the windows are large enough to accommodate the information on your How to Use page.

Note: Students found to have copied source code from the Internet will receive a failing grade for this assignment - no exceptions.

\section{Grading Rubric}

This assignment will be evaluated using a 25 point scale. Each of the specifications will be worth a varying number of points. If you do not understand any of the specifications, post immediately to the discussion board on Blackboard. As long as you meet all the specifications, you should receive full credit. Late assignments will not be accepted. 


\section{Biography}

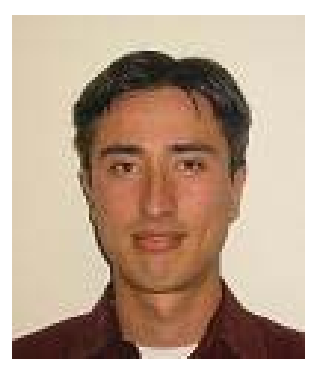

Ritzhaupt D. Ritzhaupt is an adjunct instructor for the University of North Florida. He has a B.S. in Computer and Information Sciences, Honors in the Major, Magna Cum Laude and an M.B.A. from the University of North Florida. He is currently a research assistant and software developer conducting research in instructional courseware development for information systems curriculum and is completing his Ph.D. in Instructional Technology, and Meausrement and Research at the University of South Florida.

Ritzhaupt has published and presented at multiple regional, national, and international conferences, such as the Association of Computing Machinery, the Journal of Information Systems Education, and Association of Information Technology Professionals. Ritzhaupt holds the Certified Computing Professional industry certification, and has taught in the areas of UNIX and Linux, Object-oriented software development, Internet programming, Visual Basic .NET, microcomputer applications, Java programming, geographic information systems, and COBOL Programming. 